\title{
Aerobic Power in Prepubescent Children with Different Levels of Physical Activity Potencia Aeróbica en Niños Prepubescentes con Diferentes Niveles deActividad Física
}

\author{
Luis Paulo Gomes Mascarenhas*, Marcos Tadeu Grzelczak**, William Cordeiro de Souza**,Antonio Stabelini \\ Neto***, Yamileth Chacón-Araya****, andWagner de Campos***** \\ *Universidade Estadual do Centro-Oeste, Brasil, **Universidade do Contestado, Brasil, ***Faculdade de Educação Física e Fisioterapia de \\ Jacarezinho, Brasil, ****Universidad de Costa Rica, Costa Rica, *****Universidade Federal do Paraná, Brasil
}

\begin{abstract}
The purpose of the study was to compare the aerobic power of prepubescent children (Tanner 1 stage). Participants were 95 children between 7 and 9 years old, divided into 4 physical activity level groups: a) Trained $(n=24)$, b) Sport beginners $(n=23)$, c) Active $(n=24)$, and d) Sedentary $(n$ = 24). Physical activity level was determined by a three-day physical activity diary. Subjects performed a treadmill Balk protocol to obtain their peak oxygen uptake. Comparisons were made using ANOVA two-way and post hoc Tukey followed-up the significant differences for $\mathrm{p}<0,05$. Trained, sport beginners and active children presented similar amount of physical activity level, but they significantly differ from the sedentary children $(p<0.05)$. Overall boys ( $50.67 \pm 8.52 \mathrm{ml} / \mathrm{kg} / \mathrm{min}$ ) had higher relative peak oxygen uptake than girls $(45.19 \pm 6.44 \mathrm{ml} / \mathrm{kg} / \mathrm{min})$. The gender by group interaction showed that this difference is explained by the superior values of the trained boys $(58.80 \pm 8.98 \mathrm{ml} / \mathrm{kg} / \mathrm{min})$ when compared to trained girls $(47.51 \pm$ $5.68 \mathrm{ml} / \mathrm{kg} / \mathrm{min}$ ), even though they presented the same amount of physical activity level. The trained group (53.16 $\pm 9.34 \mathrm{ml} / \mathrm{kg} / \mathrm{min})$ showed higher relative peak oxygen uptake compared to sport beginners (48.90 $\pm 6.54 \mathrm{ml} / \mathrm{kg} / \mathrm{min})$, active children $(45.46 \pm 7.50 \mathrm{ml} / \mathrm{kg} / \mathrm{min})$ and sedentary children (44.63 $\pm 9.52 \mathrm{ml} / \mathrm{kg} / \mathrm{min})$. The results suggest that prepubescent children that participate in systematized trained programs have better physiological indicators for aerobic fitness.
\end{abstract}

Key words. aerobic power, physical activity, children

Resumen. El propósito del estudio fue comparar la potencia aeróbica de niños prepubescentes (Estadio de Tanner 1). Participaron 95 niños y niñas con edades entre 7 y 9 años, divididos en 4 grupos basados en sus niveles de actividad física: a) Entrenados ( $n=24)$, b) Principiantes en deportes (n = 23), c) Activos ( $=24)$, y d) Sedentarios $(n=24)$. Los niveles de actividad física se determinaron por medio de un diario de actividad física de tres días. Los participantes realizaron el protocolo de Balke en banda sin fin para obtener el consumo de oxígeno pico. Se hicieron comparaciones con ANOVA de dos vías y post hoc de Tukey cuando se encontraron diferencias significativas a un $\mathrm{p}<0.05$. Los niños prepubescentes entrenados, principiantes en deportes y activos presentaron niveles de actividad física similares, pero fueron significativamente diferentes de los niños sedentarios ( $<<0.05$ ). En general, los niños presentaron mayor consumo de oxígeno pico (50.67 $\pm 8.52 \mathrm{ml} / \mathrm{kg} / \mathrm{min}$ ) que las niñas (45.19 $\pm 6.44 \mathrm{ml} / \mathrm{kg} / \mathrm{min})$. La interacción de sexo por grupo mostró que esta diferencia se explica por el mayor valor de los niños entrenados (58.80 $\pm 8.98 \mathrm{ml} / \mathrm{kg} / \mathrm{min})$ cuando se les comparó con las niñas entrenadas (47.51 $\pm 5.68 \mathrm{ml} / \mathrm{kg} / \mathrm{min}$ ), aunque tuvieran el mismo nivel de actividad física. El grupo entrenado (53.16 $\pm 9.34 \mathrm{ml} / \mathrm{kg} / \mathrm{min}$ ) presentó mayores valores de consumo de oxígeno pico comparados con los principiantes (48.90 $\pm 6.54 \mathrm{ml} / \mathrm{kg} / \mathrm{min})$, niños activos (45.46 $\pm 7.50 \mathrm{ml} / \mathrm{kg} / \mathrm{min})$ y niños sedentarios $(44.63 \pm 9.52 \mathrm{ml} / \mathrm{kg} / \mathrm{min})$. Los resultados sugieren que los niños prepubescentes que participan en programas de entrenamiento sistemáticos tienen mejores indicadores fisiológicos de capacidad aeróbica.

Palabras claves. potencia aeróbica, actividad física, niños

\section{Introduction}

In general, children are considered as being a very physically-active group in the population. However, the association between daily physical activity and aerobic fitness of prepubescent children is difficult to understand because of their increased amount of daily physical activity. Is the high exercise volume and intensity naturally-performed by children good enough to guarantee the appropriate development of aerobic fitness?

Aerobic power is a component of physical fitness, and the quantity of exercise needed to improve it is well-known for adults (Garber et al., 2011). However, it is less known the quantity of exercise needed to induce physiological changes leading to aerobic and strength improvements in children (Faigenbaum, Lloyd, \& Myer, 2013; Pieles, Horn, Williams, \& Stuart, 2014; Twisk, 2001).

There are studies suggesting that participation in sport activities during childhood and youth ages may be predictive of physical activity in the future (Malina, 1996; McMurray, Harrell, Bangdiwala, \& Hu, 2003). The reduction in energy expenditure caused by low levels of physical activity has been recognized as an influential factor to increase unhealthy behaviors (Johnson et al., 2000). Om the other hand, increased energy expenditure by practicing exercise has contributed to a better and efficient function of various organ systems, weight maintenance, and in the general improvement of quality of life (Malina, 1996).

Aerobic capacity is an important variable reported in the studies tracking physical activity from childhood to adulthood with the goal to demonstrate that it is a more consistent component compared to the amount of physical activity. This brings the idea that during childhood aerobic power can be a more satisfactory health parameter than a higher

Fecha recepción: 30-09-14- Fecha envío revisores: 30-09-14- Fecha de aceptación: 15-11-14 Luis Paulo Gomes Mascarenhas luismsk@gmail.com level of physical activity (Johnson et al., 2000; Malina, 1996; McMurray et al., 2003).

Studies on prepubescent children showed a positively association between physical activity levels and physical fitness (Eliakim, Scheett, Allmendinger, Brasel, \& Cooper, 2001; Rowlands, Eston, \& Ingledew, 1999). Although the majority of the studies used samples of sedentary and active children, it is difficult to understand the influence of physical activity levels and aerobic power in children's health. Thus, one question remains unclear: is the aerobic power of a regular sport training children superior when compared to children not engaged in systematic training programs? Therefore, the aim of this study was to compare the aerobic power in different groups of male and female prepubescent children; those engaged in competitive sports training, sport training beginners, active children who do not participate in regular sports training and sedentary children.

\section{Methods}

\section{Participants}

The sample consisted of 95 children (age $=8.5 \pm 0.6 \mathrm{yr}$.) divided in 4 groups: a) Trained, 12 boys and 12 girls participating in long distance running programs three times per week for more than six months; $b$ ) Sport Beginners, 11 boys and 12 girls registered in karate classes twice per week for less than two months (emphasis was learning the sport); c) Active, 12 boys and 12 girls classified as active according to the Bouchard's three-day diary (Bouchard et al., 1983); and d) Sedentary, 12 boys and 12 girls classified as sedentary by the same three-day diary. The trained, sport beginners and active children had the same daily physical activity levels. All children were considered healthy and freeof-medication. Written informed consent was obtained from parents and the protocol was approved by the Federal University of Paraná Human Research Ethics Committee. 


\section{Measurements and Procedures}

Body composition. Body mass $(\mathrm{kg})$ and height $(\mathrm{cm})$ were measured according to standard procedures (American College of Sports Medicine, 2010). Then, the body mass index $\left(\mathrm{BMI}=\right.$ mass/height $\left.{ }^{2}\right)$ was calculated. Children were measured barefoot and wore comfortable clothes. Body fat was estimated according to the Slaughter equation (Slaughter et al., 1988), as described and cross-validated in previous studies (Filaire \& Lac, 2002; Guedes \& Guedes, 2000; Rowland, Goff, Martel, \& Ferrone, 2000; Weimann, 2002).

Physical activity. Physical activity level was determined by using a three-day diary (Bouchard et al., 1983). The instrument requires to recording activities during two-days of the week (Monday and Tuesday) and one day of the weekend (Saturday). The activities were recorded according to a scale from 1 to 9 , calculating each activity energy expenditure in METS or $\mathrm{kcal} \mathrm{kg}^{-1} \cdot 15 \mathrm{~min}^{-1}$. Children recorded the activity they performed in 15 min blocks to the assistant researcher who registered the appropriated scale classification. The full-day was divided into 96 periods of $15 \mathrm{~min}$. Habitual physical activity was determined as the mean value of the three days.

Peak oxygen uptake. Aerobic power $\left(\mathrm{VO}_{2}\right)$ was measured on a treadmill with the Balke protocol, using the Parvo Medics metabolic system (MMS - 2400). The system was calibrated before each test according to the manufacture's specifications. The main advantage for choosing the Balke protocol was the constant speed (3.3 mph or 5.3 $\mathrm{km} / \mathrm{h}$ ), which enabled children to adapt to the treadmill exercise. During each stage of the protocol, only the inclination grade changed. Expired gases were collected every 15-s. The test ended when maximal effort was obtained, the heart rate reached values above $185 \mathrm{bpm}$ (Hebestreit, Staschen, \& Hebestreit, 2000; Rowland et al., 2000)), or when the participant showed physiological signs of exhaustion (i.e., hyperpnea, facial flushing, unsteady gait, sweating or dizziness) (American College of Sports Medicine, 2014).

Sexual maturation. To guarantee that all children in this sample were prepubescent, a self-assessment of pubic hair was used according to Tanner stages. This procedure is simple and it is considered to be accurate to determine sexual maturation (Bojikian et al., 2002; Hergenroeder, Hill, Wong, Sangi-Haghpeykar, \& Taylor, 1999). First, the researcher explained to each child how to proceed. Then, the subject alone wrote in an image form the number (1 to 5) which corresponded to his or her sexual maturation.

The tests were conducted only in the morning. Parents were informed that children had to sleep at least $8 \mathrm{~h}$, had to have a light breakfast and should not take part in any type of intensive exercise the day before the tests.

\section{Design and statistical analyses}

The study used an ex post facto design. The independent variables were physical activity levels and gender, and the dependent measures were body fat \%, BMI and aerobic power. Group comparisons were made using two-way ANOVA's. Tukey's post hoc followed-up the significant differences, with alpha level of 0.05 .

\section{Results}

The age, anthropometric measurements, body mass index and body fat, and physical activity level (PAL) of the participants are reported by gender and group in Table 1.

Neither the groups nor the gender differed in BMI. Therefore, the growth of the sample was considered homogeneous. The values for BMI were similar to other studies conducted with children of similar ages (Guerra, Ribeiro, Costa, Duarte, \& Mota, 2002; McMurray et al., 2003). These results were expected because there are no significant differences between boys and girls during the prepubescent years (Guedes \& Guedes, 1995; Silvestri, 1999). Nevertheless, there were gender differences in the body fat content $(\mathrm{p}<0.05)$. Girls had higher body fat values compared to boys. Other studies also reported high fat content for girls than boys even in the prepubescent years (Ball et al., 2001;

\begin{tabular}{|c|c|c|c|c|c|}
\hline Groups & & Age (yrs.) & BMI $\left(\mathbf{k g} / \mathrm{m}^{2}\right)$ & Body Fat (\%) & PAL (kcalokg-10day ${ }^{-1}$ ) \\
\hline \multirow{3}{*}{ Trai ned (n= 24) } & Boys & $8.97 \pm 0.47$ & $16.04 \pm 1.10$ & $12.86 \pm 3.80$ & $43.67 \pm 2.49$ \\
\hline & Girls & $8.67 \pm 0.85$ & $15.59 \pm 1.41$ & $16.86 \pm 4.10$ & $40.76 \pm 13.6$ \\
\hline & Total & $8.90 \pm 0.59$ & $15.81 \pm 1.26$ & $14.86 \pm 5.31$ & 42. $21 \pm 9.67$ \\
\hline \multirow{3}{*}{ Sport Beginners $(\mathrm{n}=23$ ) } & Boys & $8.53 \pm 0.75$ & $16.19 \pm 1.57$ & $14.52 \pm 4.97$ & $41.60 \pm 3.92$ \\
\hline & Girls & $8.47 \pm 0.67$ & $16.63 \pm 1.95$ & $14.48 \pm 5.82$ & $42.89 \pm 3.51$ \\
\hline & Total & $8.51 \pm 0.34$ & $15.89 \pm 1.76$ & $14.50 \pm 4.37$ & $42.24 \pm 3.69$ \\
\hline \multirow{3}{*}{ Active $(n=24)$} & Boys & $8.26 \pm 0.33$ & $16.41 \pm 1.40$ & $15.86 \pm 4.38^{+}$ & $44.06 \pm 2.62$ \\
\hline & Girls & $8.31 \pm 0.36$ & $17.11 \pm 1.92$ & $22.00 \pm 4.77$ & $41.20 \pm 2.42$ \\
\hline & Total & $8.32 \pm 0.79$ & $16.76 \pm 1.68$ & $18.94 \pm 5.47 * *$ & $42.63 \pm 2.86$ \\
\hline \multirow{3}{*}{ Sedentary $(n=24)$} & Boys & $8.21 \pm 0.60$ & $15.42 \pm 2.03$ & $15.69 \pm 4.83$ & $35.50 \pm 2.01$ \\
\hline & Girls & $8.42 \pm 0.59$ & $16.74 \pm 2.50$ & $18.41 \pm 6.59$ & $36.94 \pm 1.31$ \\
\hline & Total & $8.29 \pm 0.69$ & $16.08 \pm 2.33$ & $16.90 \pm 5.86$ & $36.22 \pm 1.81^{* * * *}$ \\
\hline \multicolumn{6}{|c|}{$\begin{array}{l}\text { Note: + +significant between-gender differences within the same group, *ignificantly different from Activ } \\
\text { and Sedentary groups, **ignifican tly different from Sport Beginners and Trained group s; }{ }^{* * * *} \text { significantly } \\
\text { different from the other groups. }\end{array}$} \\
\hline \multicolumn{6}{|c|}{ Table 2.} \\
\hline \multicolumn{6}{|c|}{$\begin{array}{c}\text { Comparisons in } \mathrm{VO}_{2} \max \text { considering the gender by group interaction } \\
\text { Groups }\end{array}$} \\
\hline \multirow{3}{*}{ Trained } & Boys & & $1.58 \pm 0.37^{+}$ & & $58.80 \pm 8.98^{+}$ \\
\hline & Girls & & $1.25 \pm 0.27$ & & $47.51 \pm 5.68$ \\
\hline & Overall & & $1.41 \pm 0.36^{*}$ & & $53.16 \pm 9.34 * *$ \\
\hline \multirow{3}{*}{ Sport Beginn ers } & Boys & & $1.32 \pm 0.24$ & & $49.96 \pm 7.85$ \\
\hline & Girls & & $1.24 \pm 0.15$ & & $47.03 \pm 5.24$ \\
\hline & Overall & & $1.28 \pm 0.20$ & & $48.90 \pm 6.54$ \\
\hline \multirow{3}{*}{ Active } & Boys & & $1.24 \pm 0.25$ & & $48.83 \pm 10.46$ \\
\hline & Girls & & $1.14 \pm 0.22$ & & $40.43 \pm 6.43$ \\
\hline & Overall & & $1.25 \pm 0.22$ & & $45.46 \pm 7.50$ \\
\hline \multirow{3}{*}{ Sedentary } & Boys & & $1.18 \pm 0.17$ & & $45.11 \pm 6.81$ \\
\hline & Girls & & $1.32 \pm 0.26$ & & $45.82 \pm 8.42$ \\
\hline & Overall & & $1.19 \pm 0.24$ & & $44.63 \pm 9.52$ \\
\hline
\end{tabular}

McMurray et al., 2003; Sleap \& Tolfrey, 2001). The active group showed higher values of body fat compared to the sport beginners and trained groups.

As depicted in table 1, there were not significant differences between boys and girls in the PAL. As expected, the sedentary group was less active than the other groups. Post hoc analysis showed no significant differences between active, sport beginners and trained groups.

The ANOVA results revealed significant main effects for gender and groups for relative and absolute $\mathrm{VO}_{2}$. In table 2 are presented means and standard deviations for aerobic power, in absolute $\left(\mathrm{L} / \mathrm{min}^{-1}\right)$ and relative values $\left(\mathrm{ml} / \mathrm{kg}^{-1} / \mathrm{min}^{-1}\right)$.

These results showed that trained boys had higher values for absolute and relative $\mathrm{VO}_{2}$ than girls (Table 2). The gender by group interaction showed that this difference is better explained by the higher values of the trained boys when compared to trained girls, even though they showed the same amount of daily physical activity levels. The trained group had higher relative $\mathrm{VO}_{2}$ compared to sport beginners, active and sedentary children. These results suggest that prepubescent children that participate in systematized trained programs show better physiological indicators for aerobic fitness. Figures 1 and 2 present the gender by group interaction for absolute and relative $\mathrm{VO}_{2}$.

\section{Discussion}

The sample analyzed was homogenous in growth and the children BMI values were considered normal according to previous research (Cole, Bellizzi, Flegal, \& Dietz, 2000). The body fat percentages were also in the levels expected for prepubescent children (Heyward \& Wagner, 2004); however, girls showed higher fat content than boys. Similar results were found in others studies (Ball et al., 2001; McMurray et al., 2003; Rowland et al., 2000; Sleap \& Tolfrey, 2001).Although girls had higher body fat \%, there were no differences in the quantity of physical activity performed during the day (PAL).

The similarity of the results between boys and girls in physical activity level were also shown in recent studies (Ball et al., 2001; Sleap \& Tolfrey, 2001; Trost et al., 2002). Other research shows that girls are less active than boys of the same age level (Boreham, Twisk, Savage, Cran, \& Strain, 1997; Eliakim et al., 2001; Epstein et al., 2001; Gavarry, Giacomoni, Bernard, Seymat, \& Falgairette, 2003; Guerra et al., 2002; Janz et al., 2002; McMurray et al., 2003; Riddoch et al., 2004). In this study, half of the sample was comprised by children who are engaged in regularphysical activity which could explain the lack of gender difference for physical activity level (Mascarenhas et al., 2005). 


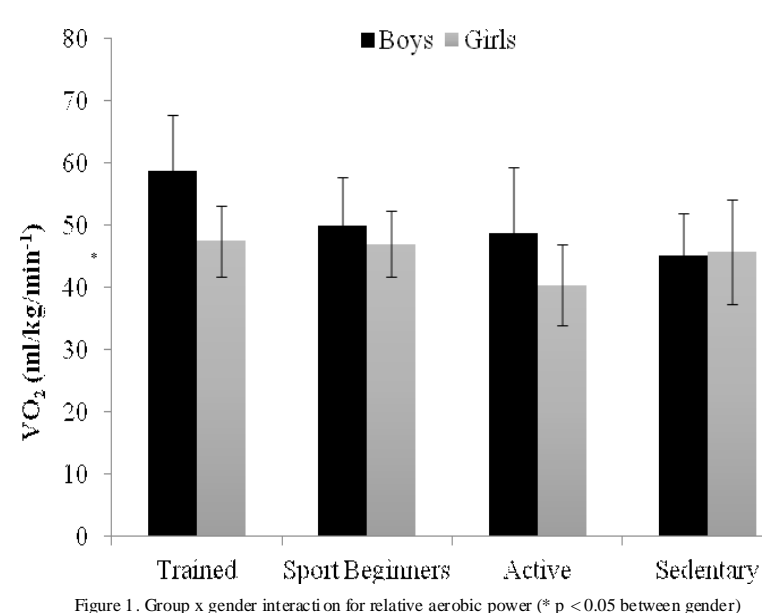

The Sedentary group performed less physical activity compared to the others groups $(\mathrm{p}<0.05)$. There were no differences among the others groups (i.e., Trained, Sport Beginners and Active). The lack of differences between the groups engaged in sports (i.e., Trained and Sport Beginners) and the Active group reflects that the daily routine performed by active children is composed by enough amounts of physical activity tasks that guarantee a similar total PAL; however, the sport practices are not a significant item in the PAL.

In spite of PAL results, there were differences in overall $\mathrm{VO}_{2}$ between the groups. Such differences cannot be attributed to a failure of the test because a maximal effort was reached at completion. TheANOVA showed that there were no significant differences in RER following exercise between groups $(p=0.25)$ or between genders $(p=0.21)$.

Overall, the results obtained by the male subjects were $50.68 \pm$ 9.81 and for girls $45.43 \pm 7.03 \mathrm{ml} \cdot \mathrm{kg}^{-1} \bullet \mathrm{min}^{-1}$. These values are similar to those reported in previous studies on subjects with the same age characteristics. For example, McMurray et al. (McMurray et al., 2003), reported $\mathrm{VO}_{2}=46.5 \pm 8.9 \mathrm{ml} \cdot \mathrm{kg}^{-1} \cdot \mathrm{min}^{-1}$ for boys and $41.3 \pm 9.1 \mathrm{ml} \cdot \mathrm{kg}$ ${ }^{1} \cdot \mathrm{min}^{-1}$ for girls. Others (Rowland et al., 2000), also reported similar mean values $\left(47.2 \pm 6.1 \mathrm{ml} \cdot \mathrm{kg}^{-1} \bullet \mathrm{min}^{-1}\right.$ for boys and $40.4 \pm 5.8$ for girls $\mathrm{ml} \cdot \mathrm{kg}^{-1} \cdot \mathrm{min}^{-1}$ ). The slightly higher values found in this study can be result of the samples' attributes. When analyzing only the Sedentary and Active groups the mean $\mathrm{VO}_{2}$ were slightly lower to those reported earlier on children of the same age (Beunen et al., 2002; Rowland et al., 2000).

In conclusion, boys showed higher aerobic power values than girls. There were no significant between-gender differences in PAL.According to the literature, even at prepubescent age, boys have significant higher values in aerobic power compared to girls (Docherty, 1996; Guerra et al., 2002; Janz, Dawson, \& Mahoney, 2000; McMurray et al., 2003; Rowland et al., 2000; Sleap \& Tolfrey, 2001). We found similar results on the sample studied, with a $10.4 \%$ difference between boys and girls.

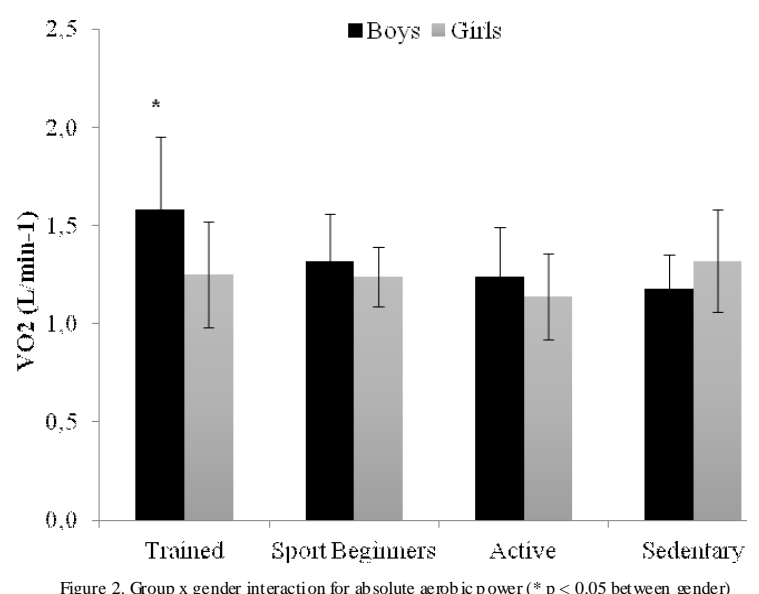

\section{References}

American College of Sports Medicine. (2010). ACSM's health-related physical fitness assessment manual. Philadelphia, PA: Lippincott Williams \& Wilkins.

American College of Sports Medicine. (2014). ACSM's quidelines for exercise testing and prescription (9th ed.). Philadelphia, PA: Lippincott Williams \& Wilkins.

Ball, E. J., O’Connor, J., Abbott, R., Steinbeck, K. S., Davies, P. S., Wishart, C., . . Baur, L. A. (2001) Total energy expenditure, body fatness, and physical activity in children aged 6-9 y. Am J Clin Nutr, 74(4), 524-528.

Beunen, G, Baxter-Jones, A. D., Mirwald, R. L., Thomis, M., Lefevre, J., Malina, R. M., \& Bailey, D. A. (2002). Intraindividual allometric development of aerobic power in 8- to 16-year-old boys. Med Sci Sports Exerc, 34(3), 503-510.

Bojikian, L. P., Massa, M., Martin, R. H. C., Teixeira, C. P., Kiss, M.A. P. D., \& Bohme, M.T. S. (2002) Female pubertal self-assessment through drawings and photos [Auto-avaliação puberal feminina por meio de desenhos e fotos]. Atividade Física e Saúde, 7(2), 34-40.

Boreham, C. A., Twisk, J., Savage, M. J., Cran, G. W., \& Strain, J. J. (1997). Physical activity, sports participation, and risk factors in adolescents. Med Sci Sports Exerc, 29(6), 788-793.

Bouchard, C., Tremblay, A., Leblanc, C., Lortie, G, Savard, R., \& Theriault, G. (1983). A method to assess energy expenditure in children and adults. Am J Clin Nutr, 37(3), 461-467.

Cole, T. J., Bellizzi, M. C., Flegal, K. M., \& Dietz, W. H. (2000). Establishing a standard definition for child overweight and obesity worldwide: international survey. BMJ, 320(7244), 1240-1243.

Docherty, D. (1996). Measurement in pediatric exercise science. Champaign, IL: Human Kinetics.

Eliakim, A., Scheett, T., Allmendinger, N., Brasel, J. A., \& Cooper, D. M. (2001). Training, muscle volume, and energy expenditure in nonobese American girls. J Appl Physiol (1985), 90(1), 3544.

Epstein, L. H., Paluch, R. A., Kalakanis, L. E., Goldfield, G. S., Cerny, F. J., \& Roemmich, J. N. (2001) How much activity do youth get? A quantitative review of heart-rate measured activity. Pediatrics, 108(3), E44.

Faigenbaum, A. D., Lloyd, R. S., \& Myer, G. D. (2013). Youth resistance training: past practices, new perspectives, and future directions. Pediatr Exerc Sci, 25(4), 591-604.

Filaire, E., \& Lac, G. (2002). Nutritional status and body composition of juvenile elite female gymnasts. J Sports Med Phys Fitness, 42(1), 65-70.

Garber, C. E., Blissmer, B., Deschenes, M. R., Franklin, B. A., Lamonte, M. J., Lee, I.-M., . . S Swain, D. P. (2011). Quantity and Quality of Exercise for Developing and Maintaining Cardiorespiratory, Musculoskeletal, and Neuromotor Fitness in Apparently Healthy Adults: Guidance for Prescribing Exercise. Medicine \& Science in Sports \& Exercise, 43(7), 1334-1359 1310.1249/ MSS.1330b1013e318213fefb.

Gavarry, O., Giacomoni, M., Bernard, T., Seymat, M., \& Falgairette, G. (2003). Habitual physical activity in children and adolescents during school and free days. Med Sci Sports Exerc, 35(3), 525-531. doi: 10.1249/01.mss.0000053655.45022.c5

Guedes, D., \& Guedes, J. E. R. P. (1995). Exercise in health promotion [Exercício físico na promoção da saúde]. London, UK: Midiograf.

Guedes, D., \& Guedes, J. E. R. P. (2000). Growth, body composition and motor performance of children and adolescents [Crescimento, composição corporal e desempenho motor de crianças e adolescentes]. Sao Paulo, Brazil: CLR Balieiro.

Guerra, S., Ribeiro, J. C., Costa, R., Duarte, J., \& Mota, J. (2002). Relationship between cardiorespiratory fitness, body composition and blood pressure in school children. J Sports Med Phys Fitness, 42(2), 207-213.

Hebestreit, H., Staschen, B., \& Hebestreit, A. (2000). Ventilatory threshold: a useful method to determine aerobic fitness in children? Med Sci Sports Exerc, 32(11), 1964-1969.

Hergenroeder, A. C., Hill, R. B., Wong, W. W., Sangi-Haghpeykar, H., \& Taylor, W. (1999). Validity of self-assessment of pubertal maturation in African American and European American adolescents. J Adolesc Health, 24(3), 201-205.

Heyward, V., \& Wagner, D. (2004). Applied Body Composition Assessment ( $2^{\text {nd }}$ ed.). Champaign, IL: Human Kinetics.

Janz, K. F., Dawson, J. D., \& Mahoney, L. T. (2000). Tracking physical fitness and physical activity from childhood to adolescence: the muscatine study. Med Sci Sports Exerc, 32(7), 1250-1257.

Janz, K. F., Levy, S. M., Burns, T. L., Tomer, J. C., Willing, M. C., \& Warren, J. J. (2002). Fatness, physical activity, and television viewing in children during the adiposity rebound period: the Iowa Bone Development Study. Prev Med, 35(6), 563-571.

Johnson, M. S., Figueroa-Colon, R., Herd, S. L., Fields, D. A., Sun, M., Hunter, G R., \& Goran, M. I. (2000). Aerobic fitness, not energy expenditure, influences subsequent increase in adiposity in black and white children. Pediatrics, 106(4), E50.

Malina, R. M. (1996). Tracking of physical activity and physical fitness across the lifespan. Res $Q$ Exerc Sport, 67(3 Suppl), S48-57.

Mascarenhas, L. P. G, Salgueirosa, F. d. M., Nunes, G. F., Martins, P. Â., Stabelini Neto, A., \& Campos, W. d. (2005). Relationship between different rates of physical activity and adiposity predictors in male and female adolescents [Relação entre diferentes índices de atividade física preditores de adiposidade em adolescentes de ambos os sexos]. Revista Brasileira de Medicina do Esporte, $11,214-218$

McMurray, R. G., Harrell, J. S., Bangdiwala, S. I., \& Hu, J. (2003). Tracking of physical activity and aerobic power from childhood through adolescence. Med Sci Sports Exerc, 35(11), 1914-1922. doi: 10.1249/01.mss.0000093612.59984.0e

Pieles, G. E., Horn, R., Williams, C.A., \& Stuart,A. G. (2014). Paediatric exercise training in prevention and treatment. Arch Dis Child, 99(4), 380-385. doi: 10.1136/archdischild-2013-303826

Riddoch, C. J., Bo Andersen, L., Wedderkopp, N., Harro, M., Klasson-Heggebo, L., Sardinha, L. B., ... Ekelund, U. (2004). Physical activity levels and patterns of 9- and 15-yr-old European children. Med Sci Sports Exerc, 36(1), 86-92. doi: 10.1249/01.mss.0000106174.43932.92

Rowland, T., Goff, D., Martel, L., \& Ferrone, L. (2000). Influence of cardiac functional capacity on gender differences in maximal oxygen uptake in children. Chest, 117(3), 629-635.

Rowlands, A. V., Eston, R. G., \& Ingledew, D. K. (1999). Relationship between activity levels, aerobic fitness, and body fat in 8- to 10-yr-old children. J Appl Physiol, 86(4), 1428-1435.

Silvestri, C. J. W. (1999). Prevalence of nutritional status and socio-economic status in the school population of 7 to 17 years in Guarapuava. (Specialist), Federal University of Paraná, Paraná, Brazil.

Slaughter, M. H., Lohman, T. G, Boileau, R. A., Horswill, C. A., Stillman, R. J., Van Loan, M. D., \& Bemben, D. A. (1988). Skinfold equations for estimation of body fatness in children and youth. Hum Biol, 60(5), 709-723.

Sleap, M., \& Tolfrey, K. (2001). Do 9- to 12 yr-old children meet existing physical activity recommendations for health? Med Sci Sports Exerc, 33(4), 591-596.

Trost, S. G., Pate, R. R., Sallis, J. F., Freedson, P. S., Taylor, W. C., Dowda, M., \& Sirard, J. (2002). Age and gender differences in objectively measured physical activity in youth. Med Sci Sports Exerc, 34(2), 350-355.

Twisk, J. W. (2001). Physical activity guidelines for children and adolescents: a critical review. Sports Med, 31(8), 617-627

Weimann, E. (2002). Gender-related differences in elite gymnasts: the female athlete triad. J Appl Physiol, 92(5), 2146-2152. doi: 10.1152/japplphysiol.00572.2001 